\title{
The Influence of the Process of Sugar Beet Storage on Its Biochemical Methane Potential
}

\author{
Natalia Mioduszewska ${ }^{1}\left(\mathbb{D}\right.$, Agnieszka A. Pilarska ${ }^{2, *} \mathbb{\infty}$, Krzysztof Pilarski $^{1}$ and \\ Mariusz Adamski ${ }^{1}$ \\ 1 Department of Biosystems Engineering, Poznań University of Life Sciences, Wojska Polskiego 28, \\ 60-624 Poznań, Poland; natalia.mioduszewska@up.poznan.pl (N.M.); pilarski@up.poznan.pl (K.P.); \\ mariusz.adamski@up.poznan.pl (M.A.) \\ 2 Department of Food Technology of Plant Origin, Poznań University of Life Sciences, Wojska Polskiego 28, \\ 60-624 Poznań, Poland \\ * Correspondence: pilarska@up.poznan.pl; Tel.: +48-61-848-73-08
}

Received: 4 September 2020; Accepted: 29 September 2020; Published: 1 October 2020

check for updates

\begin{abstract}
The manner of storage of sugar beets largely influences their physical and chemical properties, which may subsequently determine their biochemical methane potential. In this study, samples of fresh sugar beets as well as beets stored in two ways-in airtight conditions and in an open-air container-were tested. In both cases, measurements were taken on specific dates, i.e., after 4 , 8,16 and 32 weeks of storage. A decrease in $\mathrm{pH}$ was observed in all samples, with the lowest decrease occurring in hermetically stored samples. The lowest $\mathrm{pH}$ value of 3.71 was obtained for sugar beets stored in an open-air container after 32 weeks of storage. During storage, a gradual decrease in total solids was also recorded along with accompanying losses of organic matter, more significant in the case of storage in an open-air container. In subsequent storage periods, the biogas/methane production efficiency differed slightly for both methods. The highest volume of biogas was obtained for fresh sugar beets-148.23 $\mathrm{mL} \cdot \mathrm{g}^{-1}$ fresh matter (FM) - and subsequently in the 8th and 16th weeks of storage: $139.35 \mathrm{~mL} \cdot \mathrm{g}^{-1} \mathrm{FM}$ (H-airtight conditions) and $144.14 \mathrm{~mL} \cdot \mathrm{g}^{-1} \mathrm{FM}(\mathrm{O}$-open-air container), and $147.58 \mathrm{H} \mathrm{mL} \cdot \mathrm{g}^{-1} \mathrm{FM}(\mathrm{H})$ and $148.22 \mathrm{~mL} \cdot \mathrm{g}^{-1} \mathrm{FM}(\mathrm{O})$, respectively. The storage period affected the time of anaerobic decomposition of the organic matter-fresh sugar beets took the longest to ferment (26 days), while the material stored for 32 weeks took the shortest to ferment. In the experiment, the content of selected organic compounds in individual samples, i.e., sugar, methanol, ethanol, lactic acid and acetic acid, was also analysed. Within these results, significant differences were found between the samples stored using the two different methods. A high content of sugar, methanol, ethanol and other chemical compounds in the " $\mathrm{O}$ " materials showed the hydrolysis and acidogenesis processes taking place in an open-air container, with the participation of catalytic microorganisms.
\end{abstract}

Keywords: sugar beet; storage methods; methane fermentation; biochemical methane potential (BMP)

\section{Introduction}

After the accession to the European Union, much more emphasis has been put on increasing the energy security in Poland and promoting the use of green technologies in businesses and households [1,2]. Moreover, the European Union strives for increasing the renewable energy production in relation to the entire energy production. As of today, renewable energy production should account for $20 \%$ of production. However, respective European countries have their individual goals and norms in this respect [3]. When it comes to Poland, renewable energy production should amount to $15 \%$; however, it is difficult to accomplish. Each renewable energy installation contributes to reaching the intended goal. 
When it comes to the availability and stability of energy, biogas systems are more stable than photovoltaic and wind farms as they are more efficient and completely independent of weather conditions [3,4]. In Poland, biomass potential is significant as it could be effectively used in the development of agriculture installations [5]. The following soils may be used for energetic purposes: waste grounds, idle lands as well as cultivated areas used for fodder and aliment production [6,7]. If the entire agriculture acreage (waste grounds and set asides) was used for cultivating energy crops, it would give approx. $0.5 \cdot 10^{9} \mathrm{~m}^{3}$ of methane. It would constitute $3 \%$ of the annual natural gas consumption, the consumption of which amounts to $15 \cdot 10^{9} \mathrm{~m}^{3}$, depending on weather conditions [8].

Moreover, the accession to the European Union resulted in the development of new agriculture produce markets. This fact contributes to the increase in waste from agricultural production. The management of waste in agriculture tends to be bidirectional. One of the directions may be connected with direct management in order to fertilise soils; the other concerns using carbo-dioxide-free technologies occurring in biogas plants. It is worth mentioning that, in recent years, particular emphasis has been placed on issues related to the management of by-products of biomass processing. With a view to transforming these products, currently treated mainly as waste, into valuable products, various methods of valorisation are being considered. Much attention has been paid to the potential use of carbon-rich materials as a means of improving soil quality and for long-term carbon storage. These materials are known as biochars and produced by thermochemical biomass conversion processes, as discussed in detail in the works by Codignole Luz et al. $(2017,2018)[9,10]$.

Co-digestion with plant material rich in organic matter is a preferred strategy to increase the efficiency of the installation [11,12]. Therefore, maize is being grown more and more often and surplus sugar beet is frequently used as a substrate for agricultural biogas plants. However, the cultivation of maize in order to receive silage contributes to a gradual decrease in its crops [13]. Therefore, the cultivation of sugar beet, as a crop rotation, is recommended as an alternative way of obtaining biomass on favourable soils $[14,15]$. It should be added that in Poland many areas are sown with cereals (which are easier to grow than sugar beet), which results in a monoculture of crops. From the point of view of land reclamation, therefore, the reintroduction of sugar beet in crop rotation is justified. Nowadays, sugar beet is most often used for sugar production rather than energy production, such as bioethanol fuel or biogas production [16-18]. Sugar beets are characterised by a high content of sugar, which is easily dissolved in the digestion process. What is more, the dry mass of sugar beets amounts to approx. $80 \%$ of organic matter, which becomes fully decomposed afterwards. Furthermore, the high content of easily dissolved sugar results in a short duration of the full fermentation process, namely around 20 days. In comparison, the full fermentation process of maize silage lasts around 45-65 days $[19,20]$. Despite the fact that methane fermentation has been known for a long time, effective and alternative plants in terms of their energy properties should be sought. The use of new energy crops (maize silage, GPS hybrid rye, energy grasses and sugar beets) will increase the efficiency of the biogas installations. Researchers confirm that the mixture of sugar beets and substrates accelerates the fermentation process and at the same time increases the level of methane [21,22]. Bearing in mind how Polish agriculture works, the use of sugar beets is justified as it is completely consistent with the "Innovative Energy. Agriculture" energy programme introduced by the Polish Government in 2009. One of the assumptions of the abovementioned strategy is the use of plant products, such as sugar beets, in biogas plants [23,24]. The literature also provides research results proving that the by-product of sugar beet pulp fermentation can be used in agriculture, taking into account its chemical properties and microbiological standards [25]. Nutrients contained in the fermentation residues were, according to the results obtained by the author, assimilable as nutrients in mineral fertilisers. Nutrients contained in the digestate from sugar beet pulp, heavy metals and pathogenic microorganisms, including parasites, complied with the requirements that allow their use as a fertiliser in agriculture. The above considerations confirm the two-way possibility of using sugar beet pulp through anaerobic digestion (AD) for environmental protection. 
Storage technologies for maize and grass are widespread, while the storage of sugar beet causes some difficulties, which, in turn, influences the biochemical methane potential [26,27]. There are several ways of storing sugar beet roots for energy purposes. These methods include leaving a fragmented sugar beet in fresh air or storing the whole sugar beet in airtight conditions, and the latter method can be described as innovative. When storing in an open container, a fragmented root undergoes a decomposition process, resulting in the occurrence of a solid structure on the sugar beet, isolating the inner part of the sugar beet from the air. However, during the storage of the sugar beet in a closed container, there are several processes occurring in anaerobic conditions, which affect the chemical and physical properties of sugar beet [28]. This, in turn, affects the process of methane fermentation, which has a direct impact on the biochemical methanogenic potential. It is worth mentioning that substrate ensiling, although it causes a loss of up to $25 \%$ volatile solids (VS), is used, among others, in the case of orange peel waste (OPW) if the substrate needs to be stored due to a lack of capacity of a treatment process $[29,30]$. Calabrò et al. (2020) examined the possibility to increase the viability of the anaerobic digestion of OPW through ensiling and subsequent treatments. It was confirmed that biomass storage allows, in the case of OPWs, the extraction of d-Limonene (with significant VS reductions) [31].

Therefore, research was conducted in order to investigate how storage influences the biochemical methane potential (BMP). Methane fermentation was carried out for roots stored in airtight conditions as well as in an open-air container. The influence of storage on the fermentation time, biogas volume and methane content in the fermented material were taken into consideration.

\section{Materials and Methods}

\subsection{Materials}

In the experiment, fresh sugar beet delivered from a farm near the city of Poznan was used. The inoculum in the form of digested cattle slurry and maize silage pulp was provided by a local agricultural biogas plant from the Greater Poland Voivodeship. The inoculum was transported in a portable cooler with adjustable temperature. The $\mathrm{pH}$ of this material was 7.56, conductivity $25.80 \mathrm{mS} \cdot \mathrm{cm}^{-1}$, total solids (TS) $3.12 \%$ and volatile solids (VS) $71.05 \%$. Detailed characteristics of the inoculum as a digestate obtained from the same source have been included in earlier publications of the authors [32].

Physicochemical analyses of substrates were carried out according to the following standards:

- $\quad \mathrm{pH}$, potentiometric method, PN-EN 12176: 2004;

- total solids, mass method, PN-EN 12880: 2004;

- $\quad$ ignition loss (ignition residues), mass method, PN-EN 12879: 2004;

- collection of samples for chemical and physical research, PN-EN ISO 5667-13: 2011;

- $\quad$ biogas production, DIN 38414-S.8 [33];

- sugar content, polarisation method, methanol, ethanol, acetic acid, lactic acid and gas chromatography methods in an accredited external laboratory.

\subsection{Preparation for the Research}

The research was based on an analysis of the biochemical methane potential of sugar beet roots depending on the time and method of storage. The BMP was examined as follows:

- FSB-fresh roots;

- O-open-air container;

- $\mathrm{H}-$ hermetic container (airtight conditions);

- $\mathrm{O} / \mathrm{H} 4-$-after 4 weeks of storage;

- $\mathrm{O} / \mathrm{H} 8$ - after 8 weeks of storage;

- $\mathrm{O} / \mathrm{H} 16$ - after 16 weeks of storage;

- $\mathrm{O} / \mathrm{H} 32-$ after 32 weeks of storage. 
In order to store sugar beets in fully hermetic conditions, the air was drawn out of the airtight container $(\mathrm{H})$ by a suction pump. In this type of container, the roots were stored in one piece, while in the open container $(\mathrm{O})$ they were stored in a form of shredded pulp.

Obtaining hermetic conditions in the containers $(\mathrm{H})$ consisted of removing air containing microbiota causing decomposition of organic matter. In this case, as mentioned, the material was stored in its natural form, i.e., whole beet roots. This is an innovative, not yet described in the literature, way of storing sugar beet as a potential biomaterial for energy production, which does not require building storage lagoons, does not take up the land that could be otherwise used for cultivation and thus reduces investment costs. However, storing sugar beet pulp in open storage lagoons for energy purposes is commonly used, for instance, by German agricultural biogas plants [34,35]. Nonetheless, such a method has its drawbacks, the chief one being the loss of organic and mineral matter from the stored biomass, as reported in the literature [28,36]. In this paper, a comparison of both methods has been made by qualitative assessment of the substrates and their biogas yield.

\subsection{Biogas Production in Laboratory}

The substrate/inoculum ratios in the batches were calculated according to VDI Guideline 4630 (2006) [37] concerning the digestion of organic materials, characterisation of substrates, sample taking, collection of material data and digestion tests. It lists the conditions that must be met to check the biogas efficiency of substrates properly and characterises the type of inoculum that should be used. The inoculum should come from a sewage sludge digester or from a biogas plant with a similar profile of biogasified materials to the substrate tested [38,39]. It should contain $1.5-2 \%$ organic dry matter and there should be less than $10 \%$ total solids (TS) in the batches to guarantee adequate mass transfers. The $\mathrm{pH}$ values of the batches ranged from 6.8 to 7.3. The sugar beet content in the prepared substrate/inoculum mixture was $90 \mathrm{~g} \pm 8$, while the inoculum slurry was $1600 \mathrm{~g} \pm 60$.

Research on the biochemical methane potential of substrates was conducted in compliance with the norm: DIN 38414-S.8 [33]. Anaerobic digestion (AD) was conducted in batch fermentation in mesophilic conditions $\left(39^{\circ} \mathrm{C}\right)$ in a multi-chamber bioreactor, depicted in Figure 1 . The bioreactors of 21 capacity were placed in a water jacket (4) connected to a heater (1), allowing the process to be carried out within a fixed temperature range. The produced biogas flowed freely (7) to the tanks (8), where it was stored. The volume of produced biogas was measured every $24 \mathrm{~h}$ (reading from the tank scale (8)). Measurements of the concentration of methane, carbon dioxide, hydrogen sulphide, ammonia and oxygen in the biogas were carried out with a Geotech GA5000 gas analyzer (Tusnovics Instruments, Kraków, Poland). The biochemical methanogenic potential was determined as the sum of the daily biogas yields in relation to the fresh matter (FM). The amount determined in the next step was converted into biogas per tonne of total solids and per tonne of volatile solids. The process of reading out the amount of biogas yielded was completed when the daily amount of biogas yielded in 2 days fell below $0.4 \mathrm{dm}^{3}$.

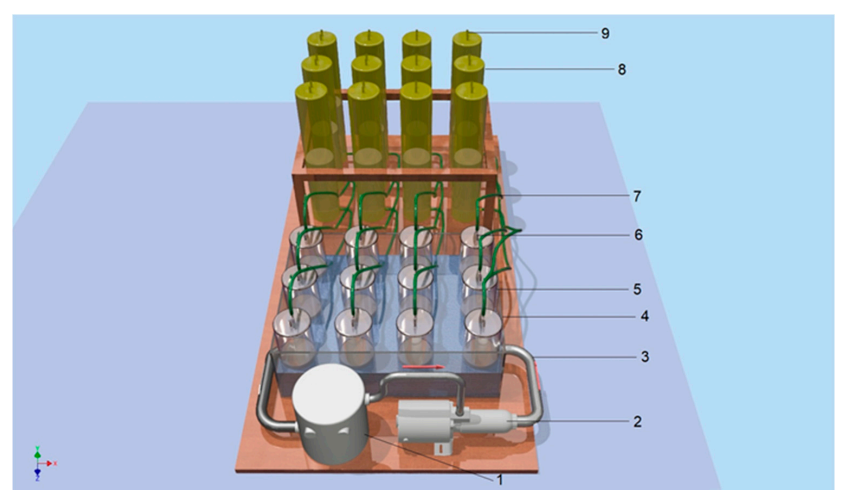

Figure 1. The anaerobic bioreactor (12-chamber section) used in the biogas production experiment: 1-water heater; 2-water pump; 3-insulated tubes for heating medium; 4 -water jacket $\left(39{ }^{\circ} \mathrm{C}\right)$; 5-bioreactor (1.4 L); 6-slurry sampling valve; 7-tube for biogas transport; 8-graduated tank for biogas; 9-gas sampling valve [40]. 


\section{Results and Discussion}

The tested samples were analyzed with regard to the hydrogen ions content. It turned out that the lowest level of $\mathrm{pH}$ was 5.93 and it concerned fresh sugar beets. After some time, $\mathrm{pH}$ decreased. It gradually decreased throughout the storage period, the most likely reason for it being the decomposition of organic matter. The $\mathrm{pH}$ changed depending on the storage method. Samples stored in airtight conditions had a lower $\mathrm{pH}$ decrease in comparison to the samples stored in open containers. The lowest $\mathrm{pH}$ values were measured in the 32nd week of storage- the $\mathrm{pH}$ of sugar beets stored in open-air container amounted to 3.71 , whereas the $\mathrm{pH}$ of sugar beets stored in airtight conditions amounted to approx. 4.93. Such significant differences between the storage methods testify to the fact that acidification processes occur during storage in the open-air container under the influence of microorganisms and the process of degradation of the material is faster than in the case of material stored in airtight conditions (this may be a vital clue in terms of storage methods).

Samples were also analysed with regard to their content of total solids (TS) as well as volatile solids (VS) in order to check the pace of the degradation of the substrates included in the sugar beet roots during the entire process of storage. The highest decrease of TS was observed in the first stage of storage, which was connected with the evaporation of water included in sugar beets. The next weeks of storage showed a decrease in the TS of the samples, which is associated with the degradation of organic matter in the substrate. This phenomenon is related to the biochemical processes taking place in the stored organic materials-most likely oxidation processes activated by solar energy freely accessing the non-insulated containers. The reduction of TS was accompanied by the reduction of VS-from week to week. The highest decrease of VS was observed in the case of sugar beets stored in the open-air container, which confirms the occurrence of degradation of organic matter during storage in open-air containers. The results of the selected physicochemical parameters are presented in Table 1.

Table 1. Physicochemical studies on the analyzed samples stored in airtight conditions and in an open-air container.

\begin{tabular}{ccccccc}
\hline Samples & $\mathbf{p H}$ & $\begin{array}{c}\text { Uncertainty of } \\
\text { the Result (+/-) }\end{array}$ & $\begin{array}{c}\text { TS } \\
\mathbf{( \% )}\end{array}$ & $\begin{array}{c}\text { Uncertainty of } \\
\text { the Result (+/-) }\end{array}$ & $\begin{array}{c}\text { VS } \\
\mathbf{( \% )}\end{array}$ & $\begin{array}{c}\text { Uncertainty of } \\
\text { the Result (+/-) }\end{array}$ \\
\hline Fresh sugar beets & 5.93 & 0.07 & 26.08 & 0.38 & 92.11 & 1.06 \\
H4 & 5.29 & 0.06 & 24.14 & 0.35 & 92.02 & 1.06 \\
O4 & 4.11 & 0.05 & 23.44 & 0.34 & 91.47 & 1.05 \\
H8 & 5.18 & 0.06 & 22.18 & 0.32 & 91.86 & 1.05 \\
O8 & 4.06 & 0.05 & 23.15 & 0.34 & 91.08 & 1.05 \\
H16 & 4.98 & 0.05 & 23.21 & 0.34 & 91.17 & 1.05 \\
O16 & 3.86 & 0.05 & 23.07 & 0.34 & 90.89 & 1.04 \\
H32 & 4.93 & 0.05 & 23.15 & 0.34 & 91.01 & 1.04 \\
O32 & 3.71 & 0.05 & 22.98 & 0.33 & 89.32 & 1.03 \\
\hline
\end{tabular}

After the analysis of the physicochemical parameters, each material/sample was examined in terms of its biogas yield, including the biochemical methane potential. The results are presented in Figures $2-4$ and Table 2.

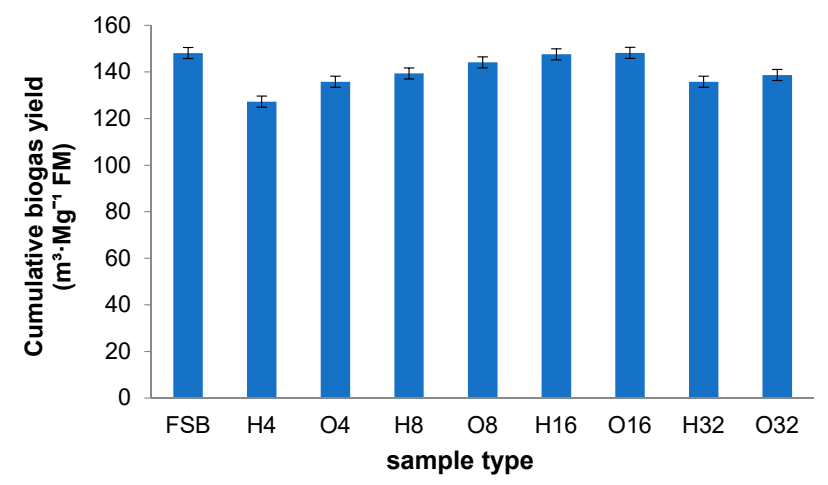

Figure 2. Cumulative biogas yield obtained from $1 \mathrm{mg}$ of fresh matter (FM). 


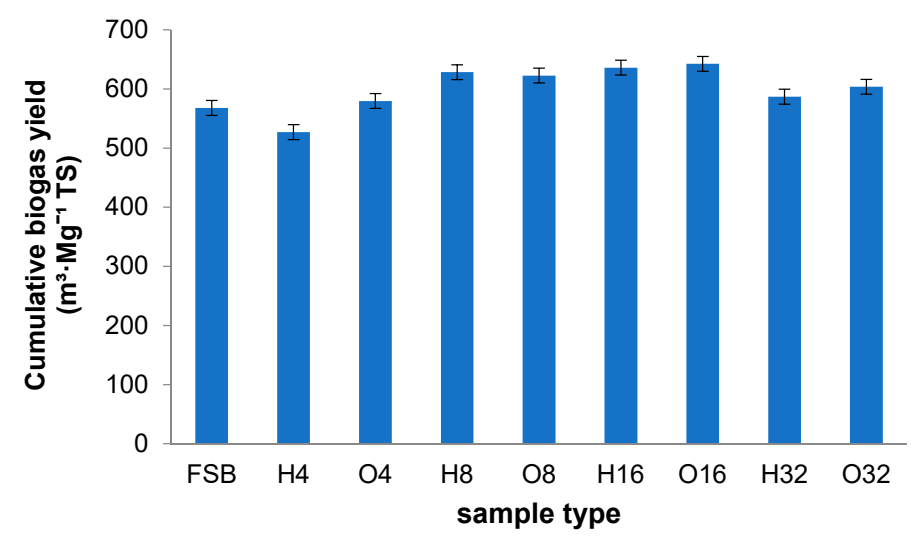

Figure 3. Cumulative biogas yield obtained from $1 \mathrm{mg}$ of total solids (TS).

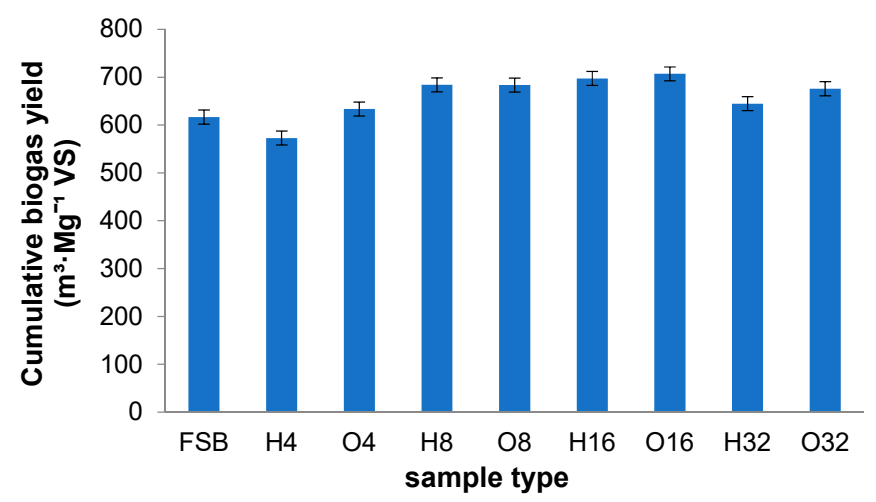

Figure 4. Cumulative biogas yield obtained from $1 \mathrm{mg}$ of volatile solids (VS).

Table 2. Methane content and fermentation time of the analyzed samples.

\begin{tabular}{ccccc}
\hline Sample Type & $\begin{array}{c}\text { Methane Level } \\
\mathbf{( \% )}\end{array}$ & $\begin{array}{c}\text { Uncertainty of the } \\
\text { Result (+/-) }\end{array}$ & $\begin{array}{c}\text { Fermentation Time } \\
\text { (day) }\end{array}$ & $\begin{array}{c}\text { Uncertainty of } \\
\text { the Result (+/-) }\end{array}$ \\
\hline Fresh sugar beets & 52.36 & 1.20 & 26 & 0.78 \\
H4 & 50.14 & 1.15 & 24 & 0.72 \\
O4 & 52.02 & 1.19 & 23 & 0.69 \\
H8 & 52.11 & 1.19 & 24 & 0.72 \\
O8 & 51.44 & 1.18 & 22 & 0.66 \\
H16 & 51.86 & 1.19 & 24 & 0.72 \\
O16 & 52.19 & 1.19 & 21 & 0.63 \\
H32 & 51.04 & 1.17 & 24 & 0.72 \\
O32 & 50.48 & 1.16 & 21 & 0.63 \\
\hline
\end{tabular}

The highest biogas production efficiency was obtained by fermenting fresh sugar beets (148.23 mL.g ${ }^{-1} \mathrm{FM} ; \mathrm{FM}$-fresh matter). The smallest amount of biogas/methane was obtained in the case of 4-week storage- -both in the case of open-air container and airtight conditions. The probable reason for obtaining smaller amounts of biogas/methane during the first sample collection was the stringiness of the sugar beet; quite surprisingly, right after harvesting, processes were taking place as if the sugar beets had still been in the soil but without the access to water. As the storage period was extended (by another 8, 16 and 32 weeks), the decomposition of the organic matter took place-both in the sugar beet stored in airtight conditions and in the pulp stored in an open-air container. After 8 and 16 weeks of storage, the biogas efficiency was increased: $139.35 \mathrm{~mL} \cdot \mathrm{g}^{-1} \mathrm{FM}-\mathrm{H}, 144.14 \mathrm{~mL} \cdot \mathrm{g}^{-1}$ $\mathrm{FM}-\mathrm{O}, 147.58 \mathrm{H} \mathrm{mL} \cdot \mathrm{g}^{-1} \mathrm{FM}-\mathrm{H}$ and $148.22 \mathrm{~mL} \cdot \mathrm{g}^{-1} \mathrm{FM}-\mathrm{O}$, respectively. The smallest amounts of biogas were obtained in the 32nd week of storage, namely, $135.84 \mathrm{~mL} \cdot \mathrm{g}^{-1} \mathrm{FM}-\mathrm{H}$ and $138.72 \mathrm{~mL} \cdot \mathrm{g}^{-1}$ $\mathrm{FM}-\mathrm{O}$. Results of the biogas efficiency of the materials kept in airtight conditions and in an open-air container were slightly higher for " $\mathrm{O}$ " containers, or comparable. Similar trends in the results were achieved when the BMP was converted into the amount of biogas in the total solids as well as into 
volatile solids. In general, the BMPs obtained for sugar beet are comparable with data found in the literature [41,42]. Suhartini et al. (2018), who recently studied the biogas potential of sugar beet pulp (SBP) under different temperature conditions and organic loading rate (OLR) with antifoam agents, noted that this substrate is a promising raw material for anaerobic digestion [43]. They also found that digestates from both mesophilic and thermophilic AD of SBP contain useful amounts of N, P and K, with a permitted concentration of $\mathrm{Ni}$, compatible with potentially toxic elements (PTE). The results of this research therefore suggest that the digestate in question has a high potential for use on agricultural and arable land. Vazifehkhoran et al. (2016), on the other hand, conducted BMP studies using samples of sugar beet pulp silage collected from six different depths of both open and closed silos (but not under airtight conditions) [28]. The BMP of the sugar beet pulp silage collected from the open silos ranged from 337 to 420 normal liters (NL) $\mathrm{CH}_{4} / \mathrm{kg}$ VS, while the BMP of the sugar beet pulp silage collected from the closed silos was slightly higher (from 411 to $451 \mathrm{NL} \mathrm{CH}_{4} / \mathrm{kg} \mathrm{VS}$ ). The energy losses correlated with the loss of volatile solids, and the depths described a linear relationship between them for both the open and closed silos.

Table 2 shows the content of methane in the biogas obtained and the time of methane fermentation. The highest volumetric methane concentration was obtained in the case of fresh sugar beets and it amounted to $52.36 \%$. However, no significant differences were observed when it comes to the content of methane in the samples, as the differences were too small to be discussed further, and the content of methane ranged from $50.14 \%$ for $\mathrm{H} 4$ to $52.19 \%$ for O16. The differences were insignificant, and it can be concluded that the method of storage did not influence the methane content in the biogas.

However, the fermentation time was different for each sample. The longest time of fermentation was observed in fresh sugar beets and it was 26 days. The shortest fermentation time concerned pulp stored for 32 weeks. In general, the time of storage significantly influences the duration of the process of decomposition of organic matter into biogas.

The samples were analyzed with regard to the level of sugar, methanol, ethanol, lactic acid and acetic acid (see Table 3); those chemical compounds are generally produced by microorganisms during storage. They have a significant impact on the final quality of the product, which undergoes the methane fermentation process.

There are significant differences between the way of storage and sugar content. The smallest amount of sugar was in the sample which was taken from the open-air container and it was $37.6 \mathrm{~g} \cdot \mathrm{kg}^{-1} \mathrm{TS}$ (O32), whereas in the case of fresh sugar beet it was $44.1 \mathrm{~g} \cdot \mathrm{kg}^{-1} \mathrm{TS}$. What is more, significant differences are noticeable in the case of higher methanol content, which is observed in the samples collected from the open-air container, in comparison to the methanol content in beets stored in airtight conditions. The methanol content in the open-air container ranged from $1.45 \mathrm{~g} \cdot \mathrm{kg}^{-1} \mathrm{TS}$ for $\mathrm{O}$ to $1.72 \mathrm{~g} \cdot \mathrm{kg}^{-1}$ for O32, while in the airtight container from $0.36 \mathrm{~g} \cdot \mathrm{kg}^{-1} \mathrm{TS}(\mathrm{H})$ to $0.49 \mathrm{~g} \cdot \mathrm{kg}^{-1} \mathrm{TS}$ (H32). Similar differences were observed in the content of ethanol, lactic acid and acetic acid, which is associated with the number of microorganisms in the open-air container, causing the degradation of organic matter by means of hydrolysis and acidogenesis. In an airtight container, microorganisms do not have the access to the biomass stored. 
Table 3. The content of the selected chemical compounds in the samples stored—in airtight conditions and in the open-air container.

\begin{tabular}{|c|c|c|c|c|c|c|c|c|c|c|c|}
\hline Sample & $\begin{array}{l}\text { Storage } \\
\text { Method }\end{array}$ & Sugar $\left(g \cdot \mathrm{kg}^{-1} \mathrm{TS}\right)$ & $\begin{array}{c}\text { Uncertainty of the } \\
\text { Result }(+/-)\end{array}$ & $\begin{array}{c}\text { Methanol } \\
\text { (g.kg-1 TS) }\end{array}$ & $\begin{array}{l}\text { Uncertainty of the } \\
\text { Result }(+/-)\end{array}$ & $\begin{array}{c}\text { Ethanol } \\
\left(\mathrm{g} \cdot \mathrm{kg}^{-1} \mathrm{TS}\right)\end{array}$ & $\begin{array}{c}\text { Uncertainty of the } \\
\text { Result }(+/-)\end{array}$ & $\begin{array}{l}\text { Acetic Acid } \\
\left.\text { (g.kg }{ }^{-1} \mathrm{TS}\right)\end{array}$ & $\begin{array}{l}\text { Uncertainty of the } \\
\text { Result }(+/-)\end{array}$ & $\begin{array}{l}\text { Lactic Acid } \\
\left(\mathrm{g} \cdot \mathrm{kg}^{-1} \mathrm{TS}\right)\end{array}$ & $\begin{array}{l}\text { Uncertainty of the } \\
\text { Result }(+/-)\end{array}$ \\
\hline Fresh sugar beets & - & 44.1 & 1.28 & ND & - & ND & - & ND & & ND & - \\
\hline \multirow{2}{*}{4} & $\mathrm{H}$ & 44.1 & 1.28 & 0.36 & 0.01 & 1.29 & 0.04 & 2.29 & 0.02 & 2.18 & 0.03 \\
\hline & $\mathrm{O}$ & 43.9 & 1.27 & 1.45 & 0.03 & 38.45 & 1.23 & 36.32 & 0.36 & 18.19 & 0.29 \\
\hline \multirow[b]{2}{*}{8} & $\mathrm{H}$ & 43.9 & 1.27 & 0.39 & 0.01 & 2.23 & 0.07 & 2.36 & 0.02 & 2.29 & 0.04 \\
\hline & $\mathrm{O}$ & 42.2 & 1.22 & 1.66 & 0.03 & 42.63 & 1.37 & 38.12 & 0.37 & 22.41 & 0.36 \\
\hline \multirow[b]{2}{*}{16} & $\mathrm{H}$ & 43.7 & 1.26 & 0.44 & 0.01 & 2.86 & 0.09 & 2.45 & 0.02 & 2.72 & 0.04 \\
\hline & 0 & 39.1 & 1.13 & 1.69 & 0.03 & 46.44 & 1.49 & 41.45 & 0.41 & 23.45 & 0.37 \\
\hline \multirow{2}{*}{32} & $\mathrm{H}$ & 43.4 & 1.26 & 0.49 & 0.01 & 2.95 & 0.09 & 2.84 & 0.03 & 3.11 & 0.05 \\
\hline & $\mathrm{O}$ & 37.6 & 1.09 & 1.72 & 0.03 & 42.61 & 1.37 & 42.16 & 0.41 & 21.54 & 0.34 \\
\hline
\end{tabular}




\section{Conclusions}

The application of two methods of sugar beet storage resulted in changes to a different degree in the physical and chemical properties.

1. During storage, the following were observed: a decrease in the $\mathrm{pH}$ (higher for samples in the open-air container) and a reduction in total solids, including volatile solids-greater in the case of the open-air container;

2. The method of storage of sugar beets had little impact on the differentiation of the BMP of the samples. The highest biogas volume was obtained for fresh sugar beets $-148.23 \mathrm{~mL} \cdot \mathrm{g}^{-1}$ FM (with 52.36\% methane). Similar (and slightly lower in airtight conditions) values were recorded in the 8 th and 16th weeks of storage $-139.35 \mathrm{~mL} \cdot \mathrm{g}^{-1} \mathrm{FM}(\mathrm{H})$ and $144.14 \mathrm{~mL} \cdot \mathrm{g}^{-1} \mathrm{FM}(\mathrm{O})$, and $147.58 \mathrm{~mL} \cdot \mathrm{g}^{-1} \mathrm{FM}(\mathrm{H})$ and $148.22 \mathrm{~mL} \cdot \mathrm{g}^{-1} \mathrm{FM}(\mathrm{O})$, respectively.

3. Large differences were observed in the content of selected organic compounds in individual samples, i.e., sugar, methanol, ethanol, lactic acid and acetic acid, which affect the quality of the stored product. The high content of sugar, methanol, ethanol and the remaining chemical compounds in the materials stored in the open-air container confirmed the decomposition of the organic matter at the stage of hydrolysis and acidogenesis, occurring under the influence of easily accessible microorganisms. In light of the above, it is more reasonable to store whole sugar beet roots in hermetic conditions rather than pulp in open storage lagoons.

Author Contributions: Conceptualization, N.M. and K.P.; methodology, N.M.; software, M.A.; validation, K.P. and A.A.P.; formal analysis, A.A.P.; investigation, N.M. and M.A.; resources, A.A.P., M.A. and K.P.; writing-original draft preparation, K.P.; writing-review and editing, A.A.P.; visualization, M.A.; supervision, K.P.; project administration, N.M.; funding acquisition, N.M. All authors have read and agreed to the published version of the manuscript.

Funding: This research received no external funding.

Conflicts of Interest: The authors declare no conflict of interest.

\section{References}

1. Pach-Gurgul, A. Renewable energy of the European Union in the conditions of economic crisis. Works Com. Ind. Geogr. Pol. Geogr. Soc. 2014, 27, 130-147.

2. Redlarski, G.; Piechocki, J.; Dąbkowski, M. Reducing air pollutant emissions from the residential sector by switching to alternative energy sources in single-family homes. Pol. J. Environ. Stud. 2013, 22, 197-203.

3. Błażejewska, K. Legal aspects of agricultural biogas production and utilization in Poland. Agric. Law Rev. 2010, 1, 97-120.

4. Pääakkönen, A.; Tolvanen, H.; Rintala, J. Techno-economic analysis of a power to biogas system operated based on fluctuating electricity. Renew. Energy 2018, 117, 166-174. [CrossRef]

5. Czapiewska, G. Creating of sustainable rural areas development based on the agricultural biogas plants. Sci. J. Facult. Econom. Sci. 2014, 18, 11-25.

6. Stańczyk, K.; Ludwik, M. Cultivation of energy crops-Possibilities of developing wastelands and arable lands where agricultural production is unprofitable. Min. Environ. 2003, 3, 71-81.

7. Sajnóg, N.; Wójcik, J. Possibilities of developing degraded and uncultivated lands in consolidation. Infrastruct. Ecol. Rural Areas 2013, 2, 155-166.

8. Ruszel, M. Evaluation of the security of natural gas supplies to Poland: The present state and the 2025 perspective. Energy Policy J. 2017, 20, 1-5.

9. Luz, F.C.; Cordiner, S.; Manni, A.; Mulone, V.; Rocco, V. Anaerobic digestion of coffee grounds soluble fraction at laboratory scale: Evaluation of the biomethane potential. Appl. Energy 2017, 207, 166-175. [CrossRef]

10. Luz, F.C.; Cordiner, S.; Manni, A.; Mulone, V.; Rocco, V. Biochar characteristics and early applications in anaerobic digestion-A review. J. Environ. Chem. Eng. 2018, 6, 2892-2909.

11. European Union (EU). Directive 2009/28/EC of the European Parliament and of the Council of 23 April 2009. Off. J. Eur. Union 2009, L140, 16-62. 
12. Pilarski, K.; Pilarska, A.A. Production efficiency of Poland farm-scale biogas plants: A case study. In Proceedings of the Renewable Energy Sources-6th International Conference, ICoRES 2019, Krynica, Poland, 12-14 June 2019. E3S Web of Conf. 2020, 154, 2002. [CrossRef]

13. Pilarski, K.; Pilarska, A.A.; Boniecki, P.; Niedbała, G.; Durczak, K.; Witaszek, K.; Mioduszewska, N.; Kowalik, K. The Efficiency of Industrial and Laboratory Anaerobic Digesters of Organic Substrates: The Use of the Biochemical Methane Potential Correction Coefficient. Energies 2020, 13, 1280. [CrossRef]

14. Nevens, F.; Reheul, D. Crop rotation versus monoculture; yield, $\mathrm{N}$ yield and ear fraction of silage maize at different levels of mineral N fertilization. Neth. J. Agric. Sci. 2001, 49, 405-425. [CrossRef]

15. Sieling, K.; Herrmann, A.; Wienforth, B.; Taube, F.; Ohl, S.; Hartung, E.; Kage, H. Biogas cropping systems: Short term response of yield performance and $\mathrm{N}$ use efficiency to biogas residue application. Eur. J. Agron. 2013, 47, 44-54. [CrossRef]

16. Przybył, J.; Mioduszewska, N.; Dach, J.; Pilarski, K. Sugar beets used for traditional purposes and for energy. An economic comparison. Agric. Eng. 2011, 7, 131-140.

17. Jacobs, A.; Auburger, S.; Bahrs, E.; Brauer-Siebrecht, W.; Christen, O.; Götze, P.; Koch, H.J.; Rücknagel, J.; Märländer, B. Greenhouse gas emission of biogas production out of silage maize and sugar beet-An assessment along the entire production chain. Appl. Energy 2017, 190, 114-121. [CrossRef]

18. Dorado, C.; Cameron, R.G.; Cooper, K. Steam explosion and fermentation of sugar beets from Southern Florida and the Midwestern United States. Biocatal. Agric. Biotechnol. 2017, 11, 26-33. [CrossRef]

19. Demirel, B.; Scherer, P. Production of methane from sugar beet silage without manure addition by a single-stage anaerobic digestion process. Biomass Bioenergy 2008, 32, 203-209. [CrossRef]

20. Kryvoruchko, V.; Machmuller, A.; Bodiroza, V.; Amon, B.; Amon, T. Anaerobic digestion of by-products of sugar beet and starch potato processing. Biomass Bioenergy 2009, 33, 620-627. [CrossRef]

21. Vindis, P.; Mursec, B.; Rozman, C.; Janzekovic, M.; Cus, F. Mini digester and biogas production from plant biomass. J. Achiev. Mater. Manuf. Eng. 2009, 35, 191-196.

22. Vindis, P.; Mursec, B.; Rozman, C.; Janzekovi, M.; Cus, F. Biogas production with the use of mini digester. J. Achiev. Mater. Manuf. Eng. 2008, 28, 99-102.

23. Igliński, B.; Buczkowski, R.; Cichosz, M. Biogas production in Poland-Current state, potential and perspectives. Renew. Sust. Energy Rev. 2015, 50, 686-695. [CrossRef]

24. Chodkowska-Miszczuk, J.; Szymańska, D. Agricultural biogas plants-A chance for diversification of agriculture in Poland. Renew. Sustain. Energy Rev. 2013, 20, 514-518. [CrossRef]

25. Baryga, A.; Połeć, B.; Małczak, E. Technological value of raw materials from sugar beet growing area fertilized with digestate from sugar beet pulp biogas plant. Plant Soil. Environ. 2017, 63, 207-212.

26. Starke, P.; Hoffmann, C. Sugar beet as a substrate for biogas production. Sugar Ind. 2011, 136, 242-250. [CrossRef]

27. Mioduszewska, N.; Adamski, M.; Smurzyńska, A.; Przybył, J.; Pilarski, K. The usefulness of sugar beets for biogas production in relations of the storage time and sugar content. E3S Web of Conf. 2018, 44, 114. [CrossRef]

28. Vazifehkhoran, A.H.; Triolo, J.M.; Larsen, S.U.; Stefanek, K.; Sommer, S.G. Assessment of the variability of biogas production from sugar beet silage as affected by movement and loss of the produced alcohols and organic acid. Energies 2016, 9, 368. [CrossRef]

29. Calabrò, P.S.; Panzera, M.F. Biomethane production tests on ensiled orange peel waste. Int. J. Heat Technol. 2017, 35, S130-S136. [CrossRef]

30. Calabro, P.S.; Paone, E.; Komilis, D. Strategies for the sustainable management of orange peel waste through anaerobic digestion. J. Environ. Manag. 2018, 212, 462-468. [CrossRef]

31. Calabro, P.S.; Fazzino, F.; Sidari, R.; Zema, D.A. Optimization of orange peel waste ensiling for sustainable anaerobic digestion. Renew. Energy 2020, 154, 849-862. [CrossRef]

32. Pilarska, A.A.; Pilarski, K.; Wolna-Maruwka, A.; Boniecki, P.; Zaborowicz, M. Use of confectionery waste in biogas production by the anaerobic digestion process. Molecules 2019, 24, 37. [CrossRef] [PubMed]

33. Characterisation of the Substrate, Sampling, Collection of Material Data, Fermentation Tests; DIN Guideline 38 414-S8; German Institute for Standardization: Berlin, Germany, 1985.

34. Dettmann, S.; Norbert, K.; Fraś, J.; Schlegel, M. Biomass Logistics in the field of renewable energy. Res. Log. Prod. 2014, 4, 307-314.

35. Van Eerd, L.L.; Congreves, K.A.; Zandstra, J.W. Sugar beet (Beta vulgaris L.) storage quality in large outdoor piles is impacted by pile management but not by nitrogen fertilizer or cultivar. Can. J. Plant Sci. 2012, 92, 129-139. [CrossRef] 
36. Dilek, F.B.; Yetis, U.; Gökcay, C.F. Water savings and sludge minimization in a beet-sugar factory through re-design of the wastewater treatment facility. J. Clean. Prod. 2003, 11, 327-331. [CrossRef]

37. Fermentation of Organic Materials Characterization of the Substrate, Sampling, Collection of Material Data, Fermentation Tests; Norm VDI 4630; German Engineers Club: Düsseldorf, Germany, 2006.

38. Pilarska, A.A.; Pilarski, K.; Witaszek, K.; Waliszewska, H.; Zborowska, M.; Waliszewska, B.; Kolasiński, M.; Szwarc-Rzepka, K. Treatment of dairy waste by anaerobic digestion with sewage sludge. Ecol. Chem. Eng. S 2016, 23, 99-115. [CrossRef]

39. Pilarska, A.A.; Pilarski, K.; Ryniecki, A.; Tomaszyk, K.; Dach, J.; Wolna-Maruwka, A. Utilization of vegetable dumplings waste from industrial production by anaerobic digestion. Int. Agrophys. 2017, 31, 93-102. [CrossRef]

40. Pilarska, A.A.; Wolna-Maruwka, A.; Pilarski, K.; Janczak, D.; Przybył, K.; Gawrysiak-Witulska, M. The use of lignin as a microbial carrier in the co-digestion of cheese and wafer waste. Polymers 2019, 11, 2073. [CrossRef]

41. Suhartini, S.; Heaven, S.; Banks, C.J. Comparison of mesophilic and thermophilic anaerobic digestion of sugar beet pulp: Performance, dewaterability and foam control. Bioresour. Technol. 2014, 152, 202-211. [CrossRef]

42. Suhartini, S.; Heaven, S.; Zhang, Y.; Banks, C.J. Antifoam, dilution and trace element addition as foaming control strategies in mesophilic anaerobic digestion of sugar beet pulp. Int. Biodeterior. Biodegrad. 2019, 145, 104812. [CrossRef]

43. Suhartini, S.; Heaven, S.; Banks, C.J. Can anaerobic digestion of sugar beet pulp support the circular economy? A study of biogas and nutrient potential. IOP Conf. Ser. Earth Environ. Sci. 2018, 131, 12048. [CrossRef]

(C) 2020 by the authors. Licensee MDPI, Basel, Switzerland. This article is an open access article distributed under the terms and conditions of the Creative Commons Attribution (CC BY) license (http://creativecommons.org/licenses/by/4.0/). 